\title{
Pelatihan Pengembangan Media Pembelajaran pada Guru MI Al Muhammady Mentoro Kecamatan Sumobito
}

\author{
Aria Indah Susanti ${ }^{1 *}$, Dwi Sari Ida Aflaha ${ }^{2}$, Imam Taufik ${ }^{3}$ \\ ${ }^{1}$ Institut Agama Islam Negeri Madura, ${ }^{2,3}$ Universitas Kahuripan Kediri \\ *ariaindahs@iainmadura.ac.id
}

\begin{abstract}
Abstrak
Pelatihan Pengembangan Media Pembelajaran pada Guru MI Al Muhammady Mentoro Kecamatan Sumobito merupakan salah satu kegiatan pengabdian masyarakat yang dilakukan dosen Institut Agama Islam Negeri Madura dan dosen Universitas Kahuripan Kediri di Madrasah Ibtidaiyah Al Muhammady Mentoro Kecamatan Sumobito Kabupaten Jombang. Kegiatan pengabdian masyarakat ini bertujuan untuk memberikan wawasan dan meningkatkan kompetensi guru khusunya ada pengembangan media pembelajaran. Materi yang diberikan tentang beberapa aplikasi offline dan online yang dapat digunakan sebagai variasi media pembelajaran agar dapat meningkatkan minat dan motivasi belajar khususnya di masa pandemi Covid-19. Pada masa pandemi Covid-19, sebagian besar bahkan hampir seluruh sekolah melaksanakan pembelajaran dari rumah. Sehingga guruguru harus kreatif dan inovatif dalam melaksanakan pembelajaran dan menyediakan media pembelajaran agar siswa dapat tetap belajar secara aktif walaupun dari rumah. Metode pelaksanaan dari kegiatan ini adalah pelatihan. Pelatihan dilaksanakan dengan memberikan/menjelaskan materi dan melakukan kegiatan praktik secara langsung. Seorang dosen memberikan materi, sedangkan dosen lainnya akan mendampingi para guru agar tidak mengalami kesulitan. Pelatihan pengembangan media pembelajaran sebagai salah satu upaya untuk membantu para guru dalam meningkatkan wawasan dan kompetensi. Hasil dari pelatihan yaitu para guru dapat meningkatkan wawasan dan pengetahuannya dalam hal mengembangkan media pembelajaran yang ditunjukkan dengan hasil pembuatan media pembelajaran selama dan setelah pelatihan.
\end{abstract}

Kata Kunci: pelatihan, pengembangan, media pembelajaran, wawasan

\section{Training on Learning Media Development for MI Al Muhammady Mentoro Teachers, Sumobito District}

\begin{abstract}
Training on Learning Media Development for MI Al Muhammady Mentoro Teachers, Sumobito District is one of the community service activities carried out by lecturers of the Madura State Islamic Institute and lecturers at Kahuripan Kediri University at Madrasah Ibtidaiyah Al Muhammady Mentoro, Sumobito District, Jombang Regency. This community service activity aims to provide insight and improve teacher competence, especially the development of learning media. The material provided is about several offline and online applications that can be used as a variety of learning media in order to increase interest and motivation to learn, especially during the Covid-19 pandemic. During the Covid-19 pandemic, most and even almost all schools carried out learning from home. So that teachers must be creative and innovative in carrying out learning and providing learning media so that students can continue to learn actively even from home. The method of implementation of this activity is training. Training is carried out by providing / explaining material and carrying out practical activities directly. A lecturer provides material, while other lecturers will accompany the teachers so they don't experience difficulties. Learning media development training as an effort to assist teachers in increasing their knowledge and competence. The result of the training is that teachers can increase their insight and knowledge in terms of developing learning media as shown by the results of making learning media during and after the training.
\end{abstract}

Keywords: training, development, instructional media, insight

\section{PENDAHULUAN}

Sejak Januari 2020 berita tentang penyebaran Covid-19 marak terdengar di media massa dari berbagai belahan dunia. Covid-19 mulai menyebar dengan pesat di Indonesia sejak bulan April 2020 yang mengakibatkan pembatasan jarak (social distacing) di 
berbagai daerah. Puncaknya yaitu pemerintah, khususnya Kementerian Pendidikan dan Kebudayaan mengeluarkan peraturan bahwa sekolah baik sekolah dasar hingga pendidikan tinggi dilarang melakukan kegiatan pembelajaran secara tatap muka.

Sekolah dasar hingga pendidikan tinggi diharuskan melakukan proses pembelajaran secara online/daring. Hal ini dilakukan berdasarkan Surat Edaran Nomor 4 Tahun 2020 Tentang Pelaksanaan Kebijakan Pendidikan Dalam Masa Darurat Penyebaran COVID. Surat edaran ini dikeluarkan oleh Menteri Pendidikan dan Kebudayaan Republik Indonesia pada 24 Maret 2020. Dijelaskan dalam surat edaran bahwa proses belajar mengajar dilaksanakan dari rumah masing-masing secara daring dan diharapkan pembelajaran daring dapat memberikan pengalaman belajar yang bermakna bagi peserta didik dengan memfokuskan pada pendidikan kecakapan hidup (Dewi, 2020: 56).

Pembelajaran daring juga dilakukan di sekolah dasar. Pembelajaran daring pada sekolah dasar turut melibatkan peran orang tua secara aktif karena dilakukan melalui bimbingan orang tua. Isman menjelaskan bahwa adanya unsur pemanfaatan internet dalam suatu proses pembelajaran merupakan ciri dari pembelajaran daring. Siswa dapat mengatur waktu belajarnya dan belajar di mana pun dengan adanya pembelajaran daring. Interaksi antara guru dan siswa dilakukan dengan perantara suatu aplikasi. Aplikasi yang sering digunakan pada pembelajaran daring di antaranya yaitu Google Classroom, video converence, telepon atau live chat, Zoom maupun melalui WhatsApp Group (Dewi, 2020: 56).

Adanya media-media pembelajaran ini merupakan salah satu bentuk inovasi dalam pendidikan yang menjawab tantangan ketersediaan media ataupun sumber belajar yang inovatif dan variatif. Namun demikian, media atau pun model pembelajaran dikatakan berhasil diterapkan juga bergantung pada pendidik dan karakteristik peserta didik. Tidak semua peserta didik sukses dalam pembelajaran daring. Hal ini diindikasikan dari semua literatur dalam e-learning. Karakteristik dari peserta didik dan lingkungan belajar menjadi salah satu faktornya (Nakayama, Yamamoto, \& Santiago, 2007).

Veithzal Rivai (2004:226) menegaskan bahwa "pelatihan adalah proses sistematis mengubah tingkah laku untuk mencapai tujuan organisasi. Pelatihan berkaitan dengan keahlian dan kemampuan pegawai dalam melaksanakan pekerjaan saat ini. Pelatihan memiliki orientasi saat ini dan membantu mencapai keahlian dan kemampuan tertentu agar berhasil melaksanakan pekerjaan". Center for Development Management and Productivity menyatakan pelatihan merupakan suatu proses pemberian bantuan kepada orang lain agar orang tersebut dapat menguasai keterampilan khusus atau pemberian bantuan perbaikan keterampilan sehingga dapat melaksanakan pekerjaannya sebaik mungkin. Melalui pelatihan, diharapkan peserta pelatihan dapat mengubah tingkah laku atau pun keterampilannya dalam melaksanakan pekerjaannya.

Beberapa permasalahan terkait pembelajaran jarak jauh atau pembelajaran secara online ini dialami oleh MI Al Muhammady Mentoro Kecamatan Sumobito Kabupaten Jombang. Permasalahan tersebut di antaranya terkait kepemilikan dan jenis handphone sebagai pendukung pembelajaran online, masalah kuota internet dan ketersediaan jaringan yang baik, dan perekonomian yang tidak merata karena adanya tambahan pengeluaran seperti internet. Oleh karena itu, guru dituntut untuk dapat menyediakan media pembelajaran yang kreatif dan inovatif serta tidak membebani siswa-siswinya, khususnya dalam hal ekonomi. 
Vol. 2, No. 1, March, 2021, pp. 32-39

e-ISSN: 2722-2004

Training on Learning Media

Development for MI Al

Muhammady Mentoro

Teachers,

Sumobito District

A. I. Susanti,

D. S. I. Aflaha,

I. Taufik

Berdasarkan wawancara dengan guru-guru MI Al Muhammady Mentoro Kecamatan Sumobito Kabupaten Jombang, mereka menyatakan bahwa para guru membutuhkan tambahan wawasan dan pengetahuan terkait perkembangan media pembelajaran yang dapat dimanfaatkan selama pembelajaran online. Media pembelajaran yang dapat digunakan siswa dan tidak terlalu membebani seperti keharusan kepemilikan kuota internet dalam jumlah besar atau handphone dengan spesifikasi yang bagus atau tinggi. Berangkat dari permasalahan inilah, peneliti memberikan pelatihan kepada guru-guru di MI Al Muhammady Mentoro untuk meningkatkan wawasan, pengetahuan, maupun kompetensi guru khususnya dalam hal pengembangan media pembelajaran online.

\section{METODE PELAKSANAAN}

Kepala Sekolah MI Al Muhammady Mentoro Kecamatan Sumobito Kabupaten Jombang dan Dosen pelaksana pengabdian masyarakat telah sepakat mengadakan pelatihan sebagai bentuk solusi atas permasalahan yang ada. Pelatihan yang diberikan dilaksanakan selama dua hari dengan beberapa materi tentang aplikasi-aplikasi yang dapat digunakan dan dimanfaatkan untuk membuat media pembelajaran. Aplikasi yang akan digunakan selama pelatihan antara lain Microsoft PowerPoint, Google Chrome, Flipbook Maker Pro, dan www.proprofs.com. Berikut kerangka kegiatan sebagai pemecahan masalah yang telah dipaparkan.

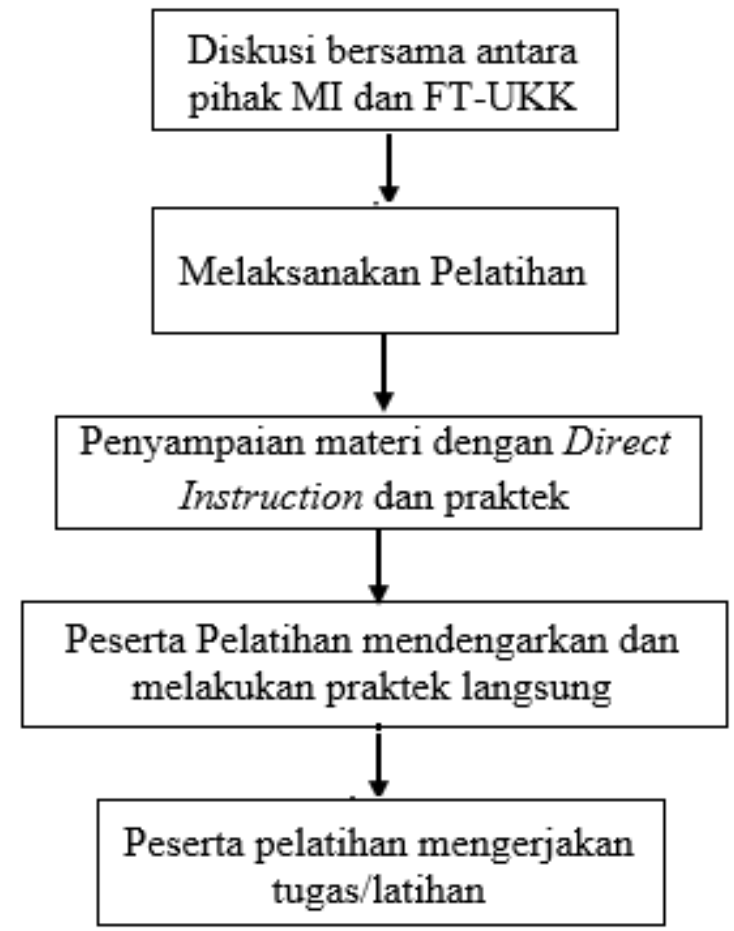

Gambar 1. Kerangka kegiatan

Pelaksanaan kegiatan pengabdian yang berupa Pelatihan Pengembangan Media Pembelajaran dilaksanakan selama dua hari yaitu Selasa, 25 Agustus 2020 dan Rabu, 26 Agustus 2020 bertempat di MI Al Muhammady Mentoro Kecamatan Sumobito Kabupaten Jombang. Kegiatan pelatihan dilaksanakan selama lima jam. 
Pelatihan berlangsung mulai pukul 08.00 WIB hingga pukul 13.00 WIB yang diikuti dan dihadiri oleh 16 peserta yaitu guru-guru MI Al Muhammady Mentoro.

Setelah pelaksanaan pelatihan, diharapkan para guru dapat membuat media pembelajaran dari beberapa aplikasi seperti yang telah dijelaskan dan dicontohkan pemateri. Untuk memenuhi target ini maka rincian kegiatan yang dilaksanakan mulai dari persiapan-persiapan yang dilakukan sebelum pelaksanaan pelatihan hingga selesai pelaksanaan pelatihan adalah sebagai berikut.

1. Mengirim surat permohonan ke MI Al Muhammady Mentoro Kecamatan Sumobito Kabupaten Jombang perihal kesediaannya untuk dijadikan mitra dalam kegiatan pengabdian masyarakat.

2. Menerima surat balasan dari MI Al Muhammady Mentoro Kecamatan Sumobito Kabupaten Jombang atas kesediaannya menjadi mitra dalam pelaksanaan kegiatan pengabdian pada tanggal 25 - 26 Agustus 2020.

3. Melakukan pengecekan kesiapan tempat dan peralatan penunjang untuk pelaksanaan kegiatan pengabdian agar dapat digunakan dengan baik pada saat kegiatan.

4. membuat modul untuk penunjang kegiatan pelatihan dan agar dapat digunakan peserta di luar pelatihan.

5. Melaksanakan kegiatan pelatihan pada Selasa, 25 Agustus 2020 dan Rabu, 26 Agustus 2020 di mulai dari pukul 08.00 hingga 16.00.

6. Meminta surat keterangan telah melaksanakan pengabdian dari Kepala MI Al Muhammady Mentoro Kecamatan Sumobito Kabupaten Jombang.

Metode kegiatan pelatihan pengembangan media pembelajaran yang digunakan yaitu direct instructional yang dilengkapi dengan kegiatan praktik secara langsung serta tugas mandiri untuk mengasah kemampuan peserta dan melihat sejauh mana pemahaman peserta pelatihan. Saat kegiatan pelatihan pengembangan media pembelajaran, pemateri akan menjelaskan sekilas tentang aplikasi yang digunakan kemudian memberikan contoh cara membuat yang diikuti oleh peserta pelatihan. Di tengah-tengah praktik, peserta dapat bertanya. Selain itu, pemateri lain yang tidak ikut memberikan materi memberikan pendampingan bagi guru-guru yang mengalami kesulitan. Peserta pelatihan juga diberi modul pelatihan untuk membantu saat praktik dan untuk digunakan belajar secara mandiri. Program pengabdian kepada masyarakat ini bertujuan untuk membantu guru-guru dalam meningkatkan kemampuan atau kompetensi dalam bidang teknologi informasi khususnya pemanfaatan aplikasi tertentu untuk pengembangan media pembelajaran.

Metode ceramah dilakukan dengan memberikan penjelasan materi dan untuk memberikan kesempatan tanya jawab bagi peserta maka digunakan metode diskusi. Sedangkan untuk memperkuat materi maka digunakan metode praktik langsung di komputer atau laptop sesuai dengan materi yang sudah dijelaskan. Peserta pelatihan juga diberi penugasan mandiri untuk melatih keterampilan dalam mengoperasikan aplikasi dan membuat media pembelajaran dengan bantuan aplikasi-aplikasi tersebut yang disertai dengan pengamatan perkembangan praktik dari instruktur.

Pelatihan dilaksanakan selama dua hari dengan durasi delapan jam per hari. Peserta dibekali dengan modul pelatihan selama kegiatan berlangsung yang digunakan sebagai acuan dalam kegiatan pelatihan. Isi materi dari modul pengembangan media pembelajaran yang disampaikan meliputi:

1. Pemanfaatan animasi di Ms. PowerPoint untuk menyajikan materi yang menarik.

2. Pembuatan soal dengan timer pada Ms. PowerPoint dan menyimpannya dalam format slideshow atau video. 
Vol. 2, No. 1, March, 2021, pp. 32-39

e-ISSN: 2722-2004

Training on Learning Media

Development for MI Al

Muhammady Mentoro Teachers, Sumobito District

A. I. Susanti,

D. S. I. Aflaha, I. Taufik

3. Pemanfaatan Google Chrome untuk membuat video dalam bentuk tangkapan layar atau pun rekaman.

4. Pemanfaatan aplikasi Flipbook Maker untuk menyajikan bahan ajar yang lebih menarik.

5. Pemanfaatan https://www.proprofs.com/games/ untuk membuat kuis berupa puzzle, scramble word, dan lain-lain yang tersedia di web tersebut dalam berbagai jenis secara mudah dan cepat.

6. Tugas mandiri membuat media pembelajaran dengan menggunakan salah satu media atau aplikasi

Setelah kegiatan pelatihan, peserta diberi kuesioner untuk mengetahui bagaimana tanggapan dan respons peserta terhadap materi yang telah diberikan. Tabel 1 berikut ini menyajikan kriteria penilaian angket respons mahasiswa.

\section{Tabel 1. Kriteria Penilaian Kuesioner Tanggapan dan Respons Peserta}

\section{Pelatihan}

\begin{tabular}{cc}
\hline Skor Rata-Rata Penilaian & Kriteria Penilaian \\
\hline $3 \leq X \leq 4$ & Sangat Baik \\
\hline $2 \leq X<3$ & Baik \\
\hline $1 \leq X<2$ & Cukup Baik \\
\hline $0 \leq X<1$ & Kurang Baik \\
\hline
\end{tabular}

Sumber: Susanti dan Lestari (2021)

\section{HASIL DAN PEMBAHASAN}

Seperti yang telah dijelaskan pada bagian metode pelaksanaan, kegiatan pengabdian masyarakat dalam bentuk pelatihan ini dilakukan dengan kombinasi dari metode ceramah (direct instruction), diskusi, dan praktik. Kegiatan ini diawali dengan penyampaian materi dengan metode ceramah (direct instruction) yaitu dilakukan dengan memberikan penjelasan materi inti. Materi disampaikan dalam bentuk praktik juga, pemateri memberikan contoh dan peserta pelatihan mengikuti step by step. Setelah itu peserta pelatihan diminta untuk melakukan latihan berupa praktik. Peserta pelatihan dapat bertanya kepada tim pemateri tentang apa yang belum dimengerti atau saat mengalami kesulitan. Setelah mengerjakan latihan, peserta pelatihan akan diminta mengerjakan tugas untuk mengasah keterampilan peserta. Instruktur mengamati perkembangan praktik para peserta tersebut. Kegiatan ini dilaksanakan selama dua hari berturut dengan materi yang berbeda.

Ada sekitar 16 orang yang hadir. Peserta pelatihan yang hadir adalah para guru dan karyawan MI Al Muhammady Mentoro Kecamatan Sumobito Kabupaten Jombang. Peserta pelatihan yang hadir sudah sesuai dengan kriteria sasaran yang diharapkan yaitu guru dan karyawan yang membutuhkan pelatihan pengembangan media pembelajaran untuk menunjang peningkatan kompetensi dan kinerja, khususnya guru-guru. Ada beberapa guru yang mengenal aplikasi PowerPoint dan Google Chrome namun dalam penggunaannya hanya tingkat dasar atau sudah lama tidak menggunakan. Sedangkan aplikasi lainnya merupakan aplikasi baru bagi para peserta pelatihan. 
Peneliti melihat beberapa kriteria atau tolak ukur untuk melihat keberhasilan pelaksanaan pelatihan pada pengabdian masyarakat ini. Terdapat tiga kriteria atau tolak ukur yang dilihat yaitu:

1. Respons positif dari peserta pelatihan

Respons peserta pelatihan diukur melalui observasi selama pelatihan berlangsung dan dengan memberikan kuesioner yang menyangkut kesan, saran, kritik, dan usulan peserta pelatihan terhadap program pengabdian masyarakat ini. Dilihat dari sikap dan respons peserta pelatihan selama kegiatan, peserta pelatihan merasa senang dan antusias dengan materi yang diberikan selama dua hari.

2 .

Meningkatnya pengetahuan dan pemahaman peserta setelah mendapat pelatihan

Peningkatan pengetahuan dan pemahaman peserta terlihat dari bagaimana peserta merespons tanya jawab yang diberikan pemateri sebagai bentuk umpan balik dan dari bagaimana peserta mengikuti kegiatan praktik step by step serta dilihat saat mengerjakan latihan dan tugas yang diberikan.

3. Meningkatnya keterampilan peserta setelah mendapat pelatihan

Keterampilan peserta pelatihan saat pelatihan diobservasi melalui pemberian latihan dan tugas-tugas tentang pembuatan media pembelajaran dengan menggunakan aplikasi-aplikasi yang telah diajarkan selama pelatihan.

Setelah pelaksanaan pelatihan, peserta diminta untuk mengisi kuesioner untuk mengetahui bagaimana tanggapan peserta mulai dari cara penyampaian materi, isi materi, jenis media yang diajarkan, dan tugas yang diberikan. Tabel 2 di bawah ini merupakan indikator-indikator yang digunakan pada kuesioner dan hasil pengisian kuesioner oleh peserta pelatihan.

Tabel 2. Hasil Kuesioner Pelatihan per Indikator

\begin{tabular}{|c|c|c|c|c|}
\hline No. & Indikator & $\begin{array}{l}\text { Total } \\
\text { nilai }\end{array}$ & $\begin{array}{c}\text { Rata- } \\
\text { rata }\end{array}$ & Kriteria \\
\hline 1 & Materi yang disampaikan mudah dimengerti & 57 & 3,56 & Sangat Baik \\
\hline 2 & $\begin{array}{l}\text { Media yang digunakan menarik dan } \\
\text { menambah motivasi belajar }\end{array}$ & 58 & 3,63 & Sangat Baik \\
\hline 3 & $\begin{array}{l}\text { Bahasa yang digunakan pemateri sulit } \\
\text { dipahami }\end{array}$ & 20 & 1,25 & Sangat Baik \\
\hline 4 & $\begin{array}{l}\text { Pemateri menyampaikan materi dan } \\
\text { melakukan praktik dengan nyaman dan sabar }\end{array}$ & 47 & 2,94 & Baik \\
\hline 5 & $\begin{array}{l}\text { Jenis-jenis media pembelajaran yang } \\
\text { diajarkan mudah digunakan dan dioperasikan }\end{array}$ & 59 & 3,69 & Sangat Baik \\
\hline 6 & $\begin{array}{l}\text { Materi yang disampaikan menambah } \\
\text { wawasan dan kemampuan dalam hal media } \\
\text { pembelajaran }\end{array}$ & 60 & 3,75 & Sangat Baik \\
\hline 7 & $\begin{array}{l}\text { Jenis-jenis media pembelajaran yang } \\
\text { diajarkan dapat disesuaikan dengan materi } \\
\text { masing-masing mata pelajaran }\end{array}$ & 57 & 3,56 & Sangat Baik \\
\hline 8 & $\begin{array}{l}\text { Jenis-jenis media pembelajaran yang } \\
\text { diajarkan menghemat biaya (paperless) }\end{array}$ & 47 & 2,94 & Baik \\
\hline 9 & $\begin{array}{l}\text { Tugas yang diberikan dapat diselesaikan dan } \\
\text { tidak membingungkan }\end{array}$ & 55 & 3,44 & Sangat Baik \\
\hline 10 & $\begin{array}{l}\text { Tugas yang diberikan mengasah kemampuan } \\
\text { peserta pelatihan }\end{array}$ & 54 & 3,60 & Sangat Baik \\
\hline 11 & $\begin{array}{l}\text { Tugas yang diberikan membantu } \\
\text { meningkatkan kemampuan peserta pelatihan }\end{array}$ & 53 & 3,31 & Sangat Baik \\
\hline
\end{tabular}

KANGMAS is a journal published by Neolectura, issued three times in one year. KANGMAS is a scientific publication media in the form of conceptual paper and field research related to social service work. It is hoped that KANGMAS can become a media for academics and researchers to publish their social service work and become a reference source for the development of social and humanity.

Our focus: Social Service

Our Scope:

Humanities,

Education,

Management,

History,

Economics,

Linguistics,

Literature,

Religion,

Politics,

Sociology,

Anthropology,

and other social service works. 
Vol. 2, No. 1, March, 2021, pp. 32-39

e-ISSN: 2722-2004

Training on Learning

Media

Development for MI Al

Muhammady

Mentoro

Teachers,

Sumobito

District

A. I. Susanti,

D. S. I. Aflaha,

I. Taufik

Dapat dilihat dari tabel di atas, bahwa secara umum keseluruhan indikator mendapat kriteria baik dan sangat baik. Hasil kuesioner pada 16 peserta dapat diinterpretasikan bahwa secara umum kegiatan pelatihan telah terlaksana dengan baik. Materi yang disampaikan dapat dimengerti oleh peserta pelatihan dan jenisjenis media pembelajaran yang diajarkan dapat dioperasikan dan pelajari dengan mudah oleh peserta pelatihan. Serangkaian kegiatan dalam pelatihan dan tugas atau latihan yang diberikan dapat meningkatkan wawasan dan kemampuan peserta dalam mengembangkan media pembelajaran. Peserta pelatihan dapat menyelesaikan tugas yang diberikan dengan baik.

Selama pelaksanaan program pelatihan ini, mulai dari tahap persiapan sampai pelaksanaannya, dapat kami sampaikan temuan-temuan sebagai berikut.

1. Pihak kepala sekolah, guru dan karyawan MI Al Muhammady Mentoro Kecamatan Sumobito Kabupaten Jombang menerima kegiatan dengan sangat terbuka dan antusias.

2. Pihak kepala sekolah menyambut baik tawaran kerja sama sebagai mitra dalam program pengabdian masyarakat ini dan program pengabdian masyarakat lainnya yang dapat membantu guru dan karyawan mengembangkan wawasan dan kemampuannya. Pihak sekolah menerima program atau kegiatan serupa di kemudian hari/di lain waktu.

3. Materi pelatihan yang diberikan sesuai dengan kebutuhan guru dan karyawan MI Al Muhammady Mentoro Kecamatan Sumobito Kabupaten Jombang. Hal ini terlihat dari respons, keaktifan, efektivitas, dan tingkat keberhasilan pelatihan pengembangan media pembelajaran bagi para peserta pelatihan. Materi ini memberikan penyegaran dan penambahan wawasan serta peningkatan keterampilan/kompetensi atas aplikasi-aplikasi di luar yang telah mereka pelajari khususnya dalam hal pengembangan media pembelajaran yang menarik dan interaktif.

4. Situasi dan kondisi pelatihan sudah kondusif bagi peserta pelatihan. Kendala yang dialami hanya pada masalah jaringan internet yang dibutuhkan pada saat penggunaan web untuk membuat media pembelajaran seperti Google Chrome dan https://www.proprofs.com/games/. Namun untuk ke depannya, jika akan mengadakan kegiatan serupa dapat dijadikan pertimbangan pemilihan materi atau perbaikan jaringan.

Pengetahuan dan keterampilan guru dan karyawan MI Al Muhammady Mentoro Kecamatan Sumobito Kabupaten Jombang terlihat baik, terbukti dari hasil observasi dan pengamatan yang dilakukan selama pelatihan berlangsung. Guru dan karyawan MI Al Muhammady Mentoro Kecamatan Sumobito Kabupaten Jombang mampu mengikuti dan menyelesaikan dengan baik latihan-latihan dan tugas-tugas yang diberikan oleh para pemateri/instruktur.

\section{SIMPULAN}

Dari serangkaian kegiatan pada pelatihan, dapat disimpulkan bahwa kegiatan pengabdian kepada masyarakat berupa Pelatihan Pengembangan Media Pembelajaran untuk Meningkatkan Wawasan dan Kompetensi Guru di MI Al Muhammady Mentoro Kecamatan Sumobito Kabupaten Jombang dapat menambah wawasan dan meningkatkan kemampuan peserta pelatihan. Hal ini 
dapat dilihat dari hasil kuesioner yang menunjukkan semua indikator berada pada kriteria baik atau sangat baik berdasarkan penilaian dari peserta pelatihan. Selain itu, peserta pelatihan sangat antusias pada saat pelatihan sehingga menambah minat dan motivasi yang memberikan hasil akhir berupa meningkatnya keterampilan peserta dalam menggunakan atau mengoperasikan aplikasi-aplikasi yang dapat menyajikan media pembelajaran yang lebih interaktif baik secara online maupun offline.

\section{DAFTAR PUSTAKA}

Depdiknas. (2002). Konsep pendidikan berorientasi kecakapan hidup (life skill) melalui pendekatan pendidikan berbasis luas (broad based education-BBE). Jakarta: Depdiknas.

Dewi, W. A. F. (2020). Dampak covid-19 terhadap implementasi pembelajaran daring di sekolah dasar. Edukatif: Jurnal Ilmu Pendidikan, 2 (1), 55-61. DOI: https://doi.org/10.31004/edukatif.v2i1.89

Kesiman, M.W.A. (2010). Laporan Akhir P2M, IbM Pelatihan Microsoft Word 2007 Untuk Anak-anak Panti Asuhan Se-Kecamatan Buleleng.

Nakayama, M., Yamamoto, H., \& Santiago, R. (2007). The impact of learner characteristics on learning performance in hybrid courses among Japanese students. Elektronic Journal E-Learning, 5 (3), 195-206.

Rivai, V. (2004). Manajemen Sumber Daya Manusia Untuk Perusahaan. Jakarta: PT. Raja Grafindo Persada.

Susanti, A. I. dan Lestari, N. A. (2021). Booklet berbasis Flipbook sebagai salah satu media pembelajaran ekologi pertanian. JICTE (Journal of Information and Computer Technology Education), 5 (1). 